\title{
Lung Function in Patients Receiving Busulphan
}

\author{
W. A. LITTLER, ${ }^{*}$ M.B., M.R.C.P. ; COLIN OGILVIE, $†$ M.D., F.R.C.P.
}

\begin{abstract}
Summary: An attempt was made to achieve earlier detection of busulphan lung (fibrosing alveolitis) and to determine its incidence by means of serial studies during life, including measurement of the gas transfer factor. Twenty-three patients were investigated over an average period of nearly two years of busulphan treatment. One case of busulphan lung was detected and subsequently confirmed at necropsy, but in the remainder there was no clinical, radiological, or physiological evidence of fibrosing alveolitis. It is concluded that the development of fibrosing alveolitis may be related to individual genetic or immunological factors rather than to busulphan dosage.
\end{abstract}

\section{Introduction}

Busulphan is an alkylating agent introduced into clinical practice by Galton in 1953. It is the treatment of choice for chronic myeloid leukaemia and is also useful in the management of other myeloproliferative disorders such as polycythaemia rubra vera and myelosclerosis.

Bone marrow depression is the principal hazard of busulphan therapy (Weatherall, Galton, and Kay, 1969), but hyperpigmentation and amenorrhoea also occur (Kyle, Schwartz, Oliner, and Dameshek, 1961). Though Oliner, Schwartz, Rubio, and Dameshek (1961) first recognized fibrosing alveolitis as a complication of prolonged busulphan therapy, only 10 clinical cases have been reported, and for most of these the total dose of busulphan and the detailed results of lung function tests were not recorded (Table I). Despite these few clinical cases Heard and Cooke (1968) found histological changes attributed to busulphan in the lungs of 6 out of 14 cases $(43 \%)$ ) of chronic myeloid leukaemia coming to necropsy. A diagnosis of pulmonary fibrosis had been made in only one of these patients during life. Heard's work suggested to us that more cases of busulphan lung might be diagnosed during life if careful observation of patients receiving the drug were maintained.

The purpose of the present report is to describe the results of serial clinical, radiological, and physiological studies in a group of patients treated with busulphan, with particular reference to the gas transfer factor.

* Medical Registrar.

The Regional Cardiothoracic Centre, Broadgreen Hospital, Liverpool 14

\section{Patients and Methods}

Twenty-three patients (12 males and 11 females) with an average age of 51 years (range 15-77) were studied. The haematological diagnoses included chronic myeloid leukaemia (17 cases), polycythaemia rubra vera ( 3 cases), myelosclerosis ( 2 cases), and thrombocythaemia ( 1 case).

The following investigations were carried out: (1) a clinical history and examination; (2) a chest radiograph; (3) the subdivisions of lung volume including vital capacity (VC), functional residual capacity (FRC), and residual volume (RV)FRC and RV were measured by a closed-circuit helium technique; (4) maximum voluntary ventilation at 80 respirations per minute (MVV); (5) the forced expiratory volume in 1 second $\left(\mathrm{FEV}_{1}\right)$; (6) arterial $\mathrm{PCO}_{2}$ by the rebreathing method; and (7) transfer factor for carbon monoxide (TLCO) by the single-breath technique. In 17 patients these investigations were carried out on two separate occasions, after an average of 14 and 21 months' treatment respectively.

The normal values for lung volumes were predicted from the formula of Baldwin, Cournand, and Richards (1948). Normal values for the gas transfer factor were predicted from the formula of Ogilvie, Forster, Blakemore, and Morton (1957).

\section{Results}

The clinical and radiological findings are presented in Table II and the results of the physiological tests in Tables III and IV. For convenience of discussion the patients were divided into two groups. Group 1 comprised 17 showing no significant impairment of gas transfer factor. Twelve of these were studied on two separate occasions (Table V). All 17 were symptom-free, and the chest radiograph was nor$\mathrm{mal}$ in every case. Group 2 comprised the following six patients showing a low transfer factor on one or more occasions:

Case 4 was the only patient in the whole series to develop "busulphan lung." His gas transfer factor was reduced to $25 \%$ of the predicted normal. He had received $1,000 \mathrm{mg}$. of busulphan over a period of 19 months. Full details of this case are reported elsewhere (Littler, Kay, Hasleton, and Heath, 1969).

Cases 11 and 21 had a low transfer factor on both occasions they were studied. These two men had severe chronic airways obstruction with an $\mathrm{FEV}_{1} \%$ of less than 50 . Both were cigarette smokers and Case 21 had been a boiler scaler for 20 years. (Table VI compares the mean gas transfer factor and $\mathrm{FEV}_{1} \%$ of these two patients with those in group 1.) Neither of these patients

TABLE I.-Review of the Clinical Cases Reported in the Literature

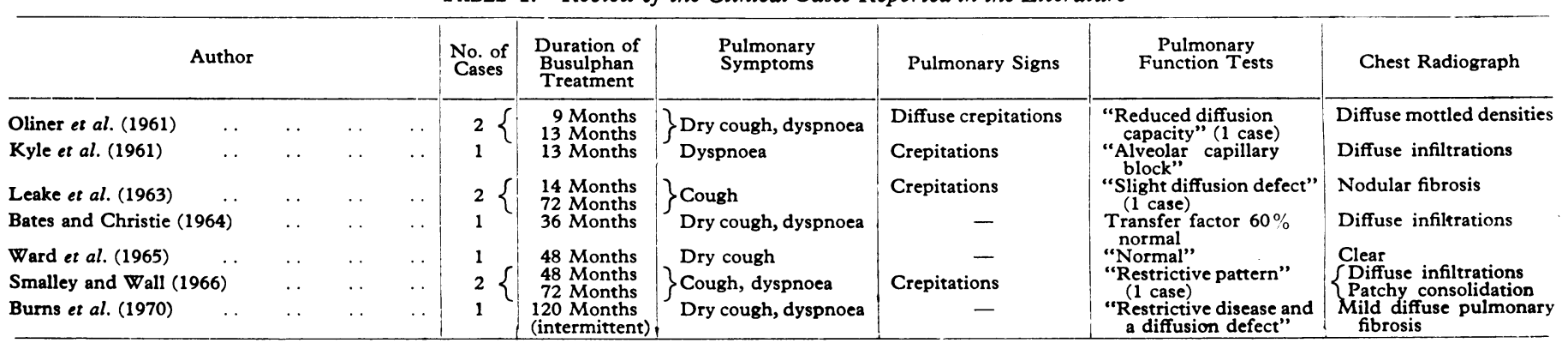


TABLE II.--Clinicol and Radiological Findings in the 23 Patients Studied

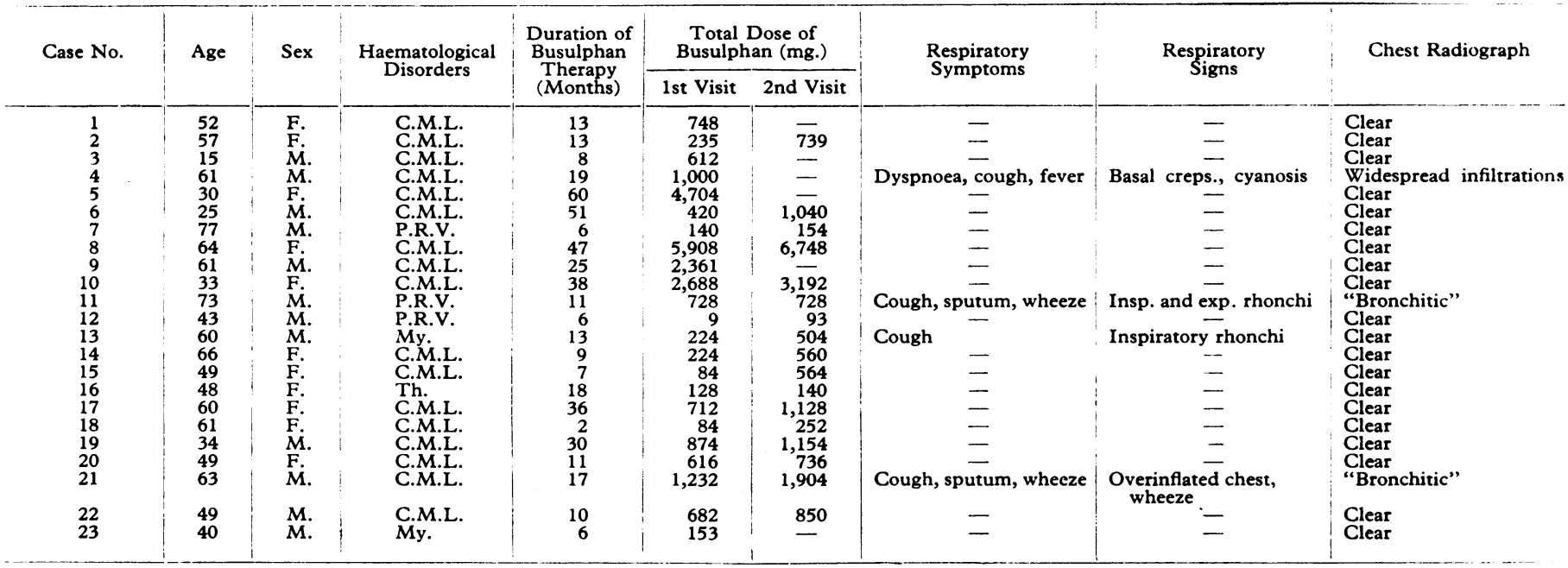

C.M.L. = Chronic myeloid leukaemia. $\quad$ P.R.V. $=$ Polycythaemia rubra vera. $\quad$ My. $=$ Myelosclerosis. $\quad$ Th. $=$ Thrombocythaemia.

TABLE III.-Physiological Findings for the 23 Patients in Groups 1 and 2 (Mean and Range of Values Shown).

\begin{tabular}{|c|c|c|c|c|c|c|c|c|c|}
\hline & & VC (1.) & FRC (1.) & RV (1.) & $\operatorname{TLC}(1)$. & $\operatorname{MVV}(1 . / \mathrm{min})$. & FEV $_{1}(\%)$ & $\mathrm{PCO}_{2}(\mathrm{~mm} . \mathrm{Hg})$ & $\begin{array}{c}\text { Transfer Factor } \\
\text { (mll/mm. } \\
\mathrm{Hg} / \mathrm{min} .)\end{array}$ \\
\hline $\begin{array}{l}\text { Group 1: } \\
\text { 1st visit } \\
\text { 2nd visit } \\
\text { Group 2: }\end{array}$ & & $\begin{array}{l}3 \cdot 13(2 \cdot 05-4 \cdot 8) \\
3 \cdot 43(2 \cdot 2-5 \cdot 1)\end{array}$ & $\begin{array}{l}2.54(1 \cdot 7-3.65) \\
3.09(2 \cdot 7-4 \cdot 7)\end{array}$ & $\begin{array}{l}2.43(0.55-3.9) \\
2.10(1.5-4.05)\end{array}$ & $\begin{array}{ll}5.2 & (2.85-6.65) \\
5.5 & (3.85-7.1)\end{array}$ & $\begin{array}{l}86(42-162) \\
95(70-160)\end{array}$ & $\begin{array}{l}75(67-83) \\
70(66-83)\end{array}$ & $\begin{array}{l}38 \cdot 3(32-43) \\
37 \cdot 7(32-41)\end{array}$ & $\begin{array}{l}28 \cdot 6(16 \cdot 1-47 \cdot 6) \\
27 \cdot 2(16 \cdot 7-39 \cdot 5)\end{array}$ \\
\hline 1 st visit & . & $\begin{array}{l}2.31(1 \cdot 7-3.4) \\
2.41(1 \cdot 7-3 \cdot 4)\end{array}$ & $\begin{array}{l}2.36(1.85-3.95) \\
3 \cdot 16(2 \cdot 1-5.5)\end{array}$ & $\begin{array}{l}1.81(1.1-2.55) \\
2.44(1.65-4.0)\end{array}$ & $\begin{array}{l}4.34(3.45-5.55) \\
4.80(3.65-7.6)\end{array}$ & $\begin{array}{l}44(40-60) \\
51(40-62)\end{array}$ & $\begin{array}{l}60(40-71) \\
59(39-71)\end{array}$ & $\begin{array}{ll}38 & (32-47) \\
41 & (40-45)\end{array}$ & $\begin{array}{l}14.0(6.4-19.7) \\
13.3(8.9-17.3)\end{array}$ \\
\hline
\end{tabular}

TABLE IV.-Transfer Factor (\% Predicted Normal) and Haemoglobin Levels $(\mathrm{g} . / 100 \mathrm{ml}$.) in the 23 Patients

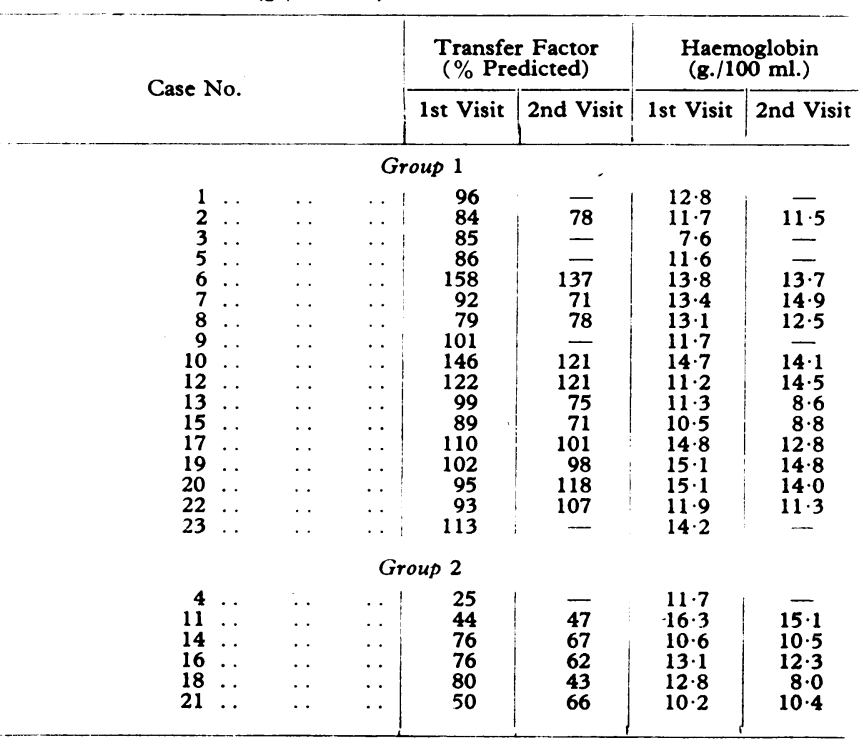

TABLE V.- Transfer Factor and Haemoglobin Levels Related to Busulphan Therapy for Patients in Group 1

\begin{tabular}{|c|c|c|c|}
\hline & & First Visit & Second Visit \\
\hline $\begin{array}{l}\text { Duration of busulphan (months) } \\
\text { Dose of busulphan (mg.) } \\
\text { Transfer factor }(\% \text { normal) } \\
\text { Haemoglobin }(\mathrm{g} . / 100 \mathrm{ml} .)\end{array}$ & . & $\begin{array}{l}14 \quad(1-39) \\
9965(9-5,908) \\
105 \quad(158-76) \\
13.93(16 \cdot 3-10 \cdot 2)\end{array}$ & \begin{tabular}{|cl}
21 & $(2-51)$ \\
1,355 & $(154-6,748)$ \\
95 & $(137-62)$ \\
$13 \cdot 43$ & $(15 \cdot 1-8 \cdot 0)$
\end{tabular} \\
\hline
\end{tabular}

TABLE VI.-Findings in Two Patients (Cases 11 and 21) with Chronic Airways Obstruction Compared with Patients in Group 1

\begin{tabular}{|c|c|c|c|c|}
\hline & & Case 11 & Case 21 & Group 1 (Mean) \\
\hline $\begin{array}{l}\text { F.E.V. } .1 \%) \\
\text { Transfer factor }(\% \text { normal }) . .\end{array}$ & $\begin{array}{ll}\cdots & \cdots \\
\therefore & \cdots\end{array}$ & $\begin{array}{l}39 \cdot 5 \\
45.5\end{array}$ & $\begin{array}{l}44 \\
55\end{array}$ & $\begin{array}{r}73 \\
100\end{array}$ \\
\hline
\end{tabular}

developed symptomatic or radiological evidence of fibrosing alveolitis, and lung function test, showed no deterioration between the first and second visits despite continued busulphan therapy.

Cases 14, 16, and 18 showed a reduction in transfer factor to below the normal range on their second visits as compared with their first. In two (Cases 16 and 18) the haemoglobin level had fallen at the second visit. In Case 14 the haemoglobin level was low at both visits.

\section{Discussion}

Fibrosing alveolitis is a rare but serious complication of busulphan therapy. Measurement of the gas transfer factor is probably the most reliable method for the early detection of fibrosing alveolitis during life. In our 23 patients receiving busulphan the transfer factor was impaired (less than $70 \%$ of predicted normal) in six, and in one of these a diagnosis of busulphan lung was established at necropsy. Two patients (Cases 11 and 21) had a low transfer factor at both visits and each showed clinical and physiological signs of obstructive airways disease without radiological evidence of fibrosing alveolitis or any deterioration in transfer factor with continued busulphan treatment. In the remaining three patients (Cases 14, 16, and 18) the transfer factor had fallen into the abnormal range at the second visit, while a further three (Cases 7, 13, and 15) showed a significant fall in transfer factor to the lower limit of the normal range. In four of these six patients a commensurate fall in the haemoglobin level occurred between the first and second visits, and a fifth patient (Case 14) was anaemic on both occasions. In none of these patients was there any clinical, spirometric, or radiological evidence of fibrosing alveolitis. Bates and Christie (1964) drew attention to the fact that the transfer factor may be low in the presence of anaemia, and an appropriate correction formula for this is now being evolved by Cotes (personal communication, 1970).

Two patients (Cases 6 and 10) had a transfer factor above $130 \%$ of their predicted normal, and one of these was a young woman taking the oral contraceptive pill. Cotes, Dabbs, McDonald, Davies, and Hall (1970) pointed out that 2 
TABLB VII.-Transfer Factor and Necropsy Findings Related to Busulphan Therapy in the Five Patients who Died

\begin{tabular}{|c|c|c|c|c|}
\hline $\begin{array}{l}\text { Case } \\
\text { No. }\end{array}$ & $\begin{array}{c}\text { Total Duration } \\
\text { of Busulphan } \\
\text { (Months) }\end{array}$ & $\begin{array}{l}\text { Total Dosage of } \\
\text { Busulphan (mg.) }\end{array}$ & $\begin{array}{c}\text { Transfer } \\
\text { Factor } \\
\text { (\% Normal) } \\
\end{array}$ & Necropsy Findings \\
\hline $\begin{array}{ll}3 & \\
5 & \\
4 & \\
9 & \end{array}$ & $\begin{array}{r}8 \\
60 \\
19 \\
25\end{array}$ & $\begin{array}{r}612 \\
4,704 \\
1,000 \\
2,361\end{array}$ & $\begin{array}{r}85 \\
86 \\
25 \\
101\end{array}$ & $\begin{array}{l}\text { No fibrosing alveolitis } \\
\text { No fibrosing alveolits } \\
\text { "Busulphan lung" } \\
\text { No necropsy. } \\
\text { Antemortem chest } \\
\text { radiograph-clear }\end{array}$ \\
\hline $1 \quad$. & 13 & 748 & 96 & $\begin{array}{l}\text { No necropsy. } \\
\text { Antemortem chest } \\
\text { radiograph-clear }\end{array}$ \\
\hline
\end{tabular}

to $3 \%$ of normal people have an unusually high transfer factor, and A. Seaton (personal communication, 1970) found high transfer factors in women taking the contraceptive pill.

Five patients (Cases 1, 3, 4, 5, and 9) have died since the study was begun. One death (Case 4) resulted from fibrosing

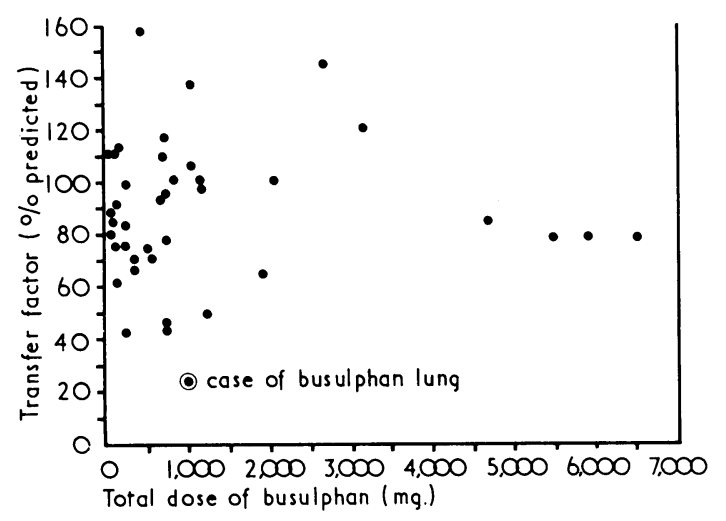

Relationship between transfer factor and total busulphan dosage.

alveolitis due to "busulphan lung." The other four patients died after a myeloblastic crisis, and in two of these no histological abnormality of the lung was found at necropsy. In the other two cases permission for necropsy was refused, but antemortem chest radiographs and physiological studies were normal. Two of these patients had received a much larger dose of busulphan than the patient who developed fibrosing alveolitis (Table VII), and a further six patients who are alive and well also received a dose in excess of $1,000 \mathrm{mg}$. (see Table II). The lack of any relationship between busulphan dosage and transfer factor is illustrated in the Chart. Hence the development of fibrosing alveolitis may be related to the genetic or immunological constitution of the patient rather than to the dose or duration of busulphan therapy.

The preliminary results of this study suggest that lung damage, detectable during life, is a relatively uncommon complication of busulphan treatment, occurring in only 1 out of 23 patients closely studied over an average period of nearly two years.

We are indebted to Dr. David Weatherall for his constant encouragement and for allowing us to study so many patients under his care. We would also like to thank Dr. J. Forshaw, Dr. P. Robb, Dr. J. Meecham, Dr. J. Campbell, Dr. J. Carmichael, and Professor Donald Heath and his department for their help with various aspects of this work. We are grateful to Miss $\mathrm{S}$. Williams and Mrs. M. Deakin for technical assistance.

REFERENCES

Baldwin, E. deF., Cournand, A., and Richards, D. W., jun. (1948). Medicine, $27,243$.

Bates, D. V., and Christie, R. V. (1964). Respiratory Function in Disease Philadelphia, Saunders.

Burns, W. A., McFarland, W., and Matthews, M. J. (1970). American Review of Respiratory Disease, $101,408$.

Cotes, J. E., Dabbs, J. M., McDonald, A., Davies, S. E., and Hall, A. M. (1970). Lancet, 1, 626.

Heard, B. E., and Cooke, R. A. (1968). Thorax, 23, 187.

Kyle, R. A., Schwartz, R. S., Oliner, H. L., and Dameshek, W. (1961). Blood, 18, 497.

Leake, E., Smith, W. G., and Woodliff, H. J. (1963). Lancet, 2, 432.

Littler, W. A., Kay, J. M., Hasleton, P. S., and Heath, D. (1969). Thorax, 24, 639 .

Ogilvie, C. M., Forster, R. E., Blakemore, W. S., and Morton, J. W. (1957), fournal of Clinical Investigation, 36,

Oliner, H., Schwartz, R., Rubio, F., and Dameshek, W. (1961). American

Fournal of Medicine, 31, 134.
Smalley, R. V., and Wall, R. L. (1966). Annals of Internal Medicine 64, 154.

Smalley, R. Medicine, 63, 654 .

Weatherall, D. J., Galton, D. A. G., and Kay, H. E. M. (1969). British Medical fournal, 1, 638

\title{
Interference of Iron with the Absorption of Tetracyclines in Man
}

\author{
P. J. NEUVONEN,* M.D. ; G. GOTHONI, † M.D. ; R. HACKMAN, $\ddagger$ M.SC. ; K. af BJÖRKSTEN, $\$ M.SC.
}

\begin{abstract}
Ummary: Ferrous sulphate administered together with tetracycline and three of its derivatives-oxytetracycline, methacycline, and doxycycline-was found seriously to impair the absorption of these antibiotics. Thus even small doses of iron taken simultaneously should be avoided during tetracycline treatment.
\end{abstract}

\section{Introduction}

Most tetracycline derivatives are rapidly but incompletely absorbed from the gastrointestinal tract. As these substances are generally considered to be bacteriostatic, their plasma

\footnotetext{
* Instructor in Department of Pharmacology, University of Helsinki, Helsinki 17, Finland.

† Medical Director, Medica Ltd., Helsinki.

\# Head of Pharmacological Department, Medica Ltd., Helsinki.

\$ Head of Bacteriological Department, Medica Ltd., Helsinki.
}

levels during therapy should never be allowed to fall below the minimum inhibitory concentration. Thus it is of great importance to avoid situations that may impair absorption and lead to therapeutically inadequate plasma concentrations. Milk, antacids, and bivalent and trivalent cations are known to reduce the absorption of tetracyclines (Waisbren and Hueckel, 1950; Dearborn et al., 1957; Rosenblatt et al., 1966), possibly by formation of chelates (Albert and Rees, 1956).

Since it is not uncommon for patients on tetracyclines also to receive preparations containing iron, we considered it valuable to study the effect of iron given simultaneously on the absorption of various tetracyclines.

\section{Methods}

The subjects were healthy medical students aged 20-24, weighing $60-80 \mathrm{~kg}$., who volunteered for the experiment. Each 